[Clark, J. A. (2005). Teaching and Research: The Canterbury Declaration. New Zealand Annual Review of Education, 14, pp. 111-129]

\section{Teaching and Research: The Canterbury Declaration and Popper's Legacy for Teacher Educators}

\section{JOHN CLARK}

\section{Abstract:}

The year 2004 was a watershed one for teacher education. The first results from the Performance Based Research Fund (PBRF) were announced, a Tertiary Education Commission report suggested that there should be clearer differences between the various tertiary education institutions, and two universities/ colleges of education have merged, with the remaining two pairs in negotiation. These events have brought particularly strong new pressures to bear upon teacher education. Research has assumed greater importance, both as a means to increased productivity and in its role as an underpinning to good teaching. That teaching be research-directed is both a legislative requirement and a philosophical imperative. One of the most elegant justifications is to be found in the Canterbury Declaration of 1945 where the hand of Karl Popper is clearly evident. In this article the legacy of his views for teacher education are explored in relation to PBRF and the institutional mergers.

$\mathrm{T}$ he year 2004 was a momentous one for tertiary education in New Zealand, in at least three important respects. To begin with, the Tertiary Education Commission (TEC) released the results of the first Performance Based Research Fund (PBRF) exercise. Secondly, the TEC published its report on the distinctive contribution of the various tertiary education institutions, and thirdly, two mergers of universities and colleges of education were approved (Auckland/ACE; Victoria University/WCE) and discussions between the remaining two pairs (Canterbury/Christchurch; Otago/Dunedin) were announced, with mergers likely in in the future.

\section{John Clark}

For teacher education, all of this has heralded in a "quiet revolution" which has transformed the field. The PBRF results (Tertiary Education Commission, 2004a) clearly differentiated the universities from the other institutions, especially the polytechnics and colleges of education; the universities scored highly while the latter two fared poorly, which was to be expected, given the different emphases these institutions give to research. The two already merged universities/colleges of education (Waikato/Hamilton; Massey/Palmerston North) occupied the middle ground. With the next PBRF exercise scheduled for 2007, how the six major teacher education institutions (all presumably merged by then), will be ranked remains a matter of conjecture. But if the 2004 data are any guide to future rankings, there will be changes to the 2004 order.

The recent Tertiary Education Commission report (2004b) on the distinctive contributions of tertiary education institutions sought to introduce sharper boundaries between the various sectors of tertiary education, especially between the universities, polytechnics and the plethora of private providers. The universities were expected to focus more on postgraduate study and less on pre-university learning and place greater emphasis on the teaching-research relationship, a matter of considerable significance, given the recent institutional mergers.

The mergers of universities and colleges of education began in the early 1990s, and it was perhaps only a matter of time before the political/economic conditions were such that the colleges in particular felt there was little alternative but to merge with their local universities. The year 2004 was a watershed in this respect, with two mergers cemented in and the remaining two imminent. In some respects the mergers are more like take-overs, if the experiences of the first two mergers is any guide. University structures, processes and procedures were extended to encompass the newly incorporated units, and the colleges lost many of their established traditions and ways of doing things.

In the light of the PBRF results and the sharpening up of institutional differences, the focus on increased research productivity and the importance of the teaching-research nexus in degree programmes have begun to assert a powerful influence on teacher education not felt until recently, but one likely to be felt even more powerfully in the future. For the day-to-day lives of teacher educators, the imperative to undertake more research at the expense of time previously devoted to teaching, coupled with the expectation that their teaching be research-based, will place new demands upon their 
professional practice and will inevitably alter the very nature of their work. For teacher educators, research is not an optional extra: not only is it a legislative requirement but more importantly it is, philosophically, a conceptually fundamental component of tertiary education.

In this article, the legislative requirement of the teaching-research relationship is set out, followed by one of the most elegant justifications for the relationship, that contained in the Canterbury Declaration of 1945 and bearing the unmistakable imprint of Karl Popper. The legacy of this defence of research-based teaching is still felt today, and nowhere more forcefully for teacher educators than in the PBRF exercise and the institutional mergers.

\section{Legislative Framework}

At the most general level, there need be no connection between teaching and research. Teaching can be as simple as showing a child how to tie a shoe lace; no research is required for this. Research can be undertaken (and often is), whose findings are deeply buried in obscure journals and taught to no-one. So, for everyday teaching and some research, no links obtain between the two activities. This is also probably true with formal teaching in primary and secondary schools, and in research institutions geared to commercial utilisation. But this is not the case for tertiary education where, legislatively, a tight association is specified. The Education Act 1989 Section 162 (4)(a) and (b) has this to say:

(a) That universities have all the following characteristics and other tertiary institutions have one or more of those characteristics.

(i) They are primarily concerned with more advanced learning, the principal aim being to develop intellectual independence;

(ii) Their research and teaching are closely interdependent and most of their teaching is done by people who are active in advancing knowledge;

(iii) They meet international standards of research and teaching;

(iv They are a repository of knowledge and expertise;

(v) They accept a role as critic and conscience of society.

Section 162 (4) (b) (i)-(iv) spells out in more detail the type of teaching and research expected of colleges of education, polytechnics, universities and wananga. ${ }^{1}$ On the nature of degrees, which the larger teacher education institutions award for pre-service preparation, Section 254 (3) (a) of the Act states that a degree,

Recognises the completion of a course of advanced learning that:

(a) is taught mainly by people engaged in research.

The Tertiary Education Commission report, The Distinctive Contribution of Tertiary Education Organizations (2004b), cited the statement above in its section on the nature of undergraduate degrees. The TEC also observed that its predecessor, the Tertiary Education Advisory Commission (TEAC) had earlier recommended that the statute should be amended so that undergraduate degrees be taught by people with a "comprehensive and current knowledge of their discipline and the skills to communicate this knowledge" (2001, p. 111). The TEAC thought this would align New Zealand more with international practice. However, the TEC wisely rejected this broader definition, going on to note that, under the Education Act, a defining characteristic of universities is that "their research and teaching are closely interdependent and most of their teaching is done by people who are active in advancing knowledge" (Education Act, 1989, s 162 (4) (a)), so "it would therefore be expected that under any scenario universities would continue to link research and teaching at all degree levels" (Tertiary Education Commission, 2004b, p. 30). This is certainly something the universities and teacher education providers must hold to be non-negotiable.

So much for the legislative requirement. Whether it is acted upon remains to be seen. That it ought to be is beyond question. But this should not be a matter of legislative compulsion but rather of philosophical persuasion, and in New Zealand there is a short history of this to be told.

\section{Canterbury Declaration}

The report of the Royal Commission on University Education in New Zealand (Reichel-Tate report) in 1925 recognised the fundamental link between teaching and research, stating, "The proper interaction of teaching and research is of the very essence of the highest education" and "Teacher and student in a University should be engaged jointly in a voyage of discovery in search of truth" (pp. 75-76), or as Socrates put it so long ago:

... that to let no day pass without discussing goodness and all the other subjects about which you hear me talking and examining both 
myself and others is really the very best thing that a man can do, and that life without this sort of examination is not worth living. (Plato, 1969, pp. 71-72)

Socrates gave his life for this: we are more fortunate for the legislative protection of being "critic and conscience for society", although we may wonder how many of us truly are Socrates' heirs!

The Reichel-Tate recommendations fell on deaf ears for twenty years until the Canterbury Declaration in 1945, titled "Research and the University" (Allan, et al., 1991, pp. 72-73). This was written by six teachers of the University of New Zealand, one of whom is of particular significance. ${ }^{2}$ Let Professor Parton, one of the six, tell the story:

Canterbury had been especially influenced by Dr Karl Popper, an influence which was expressed with particular vigour in a pamphlet Research and the University published in July 1945. The occasion for the pamphlet was the imminent departure of Popper to the London School of Economics. It was initiated in the home of Professor R. S. Allan between Allan, Popper, J. Packer and the writer. Popper was the principal author of the discussion, which was then drafted by Allan, with the addition of material from talks given by himself and the writer in the previous year. Popper organised the addition of the signatures of J. C. Eccles (Otago) and H. G. Forder (Auckland). The essence of the argument was what had been previously stated in the Reichel and Tate report on the university system twenty years earlier (1925). (Parton, 1991, p. 74)

So much for the history of how "Research and the University" came to be. What was the "Canterbury Declaration" all about? To give the full flavour, the ideal sketched out by Popper needs to be quoted at length:

We regard teaching and research not as separate functions of a University teacher, but as complementary parts of a single activity.

We do not accept the point of view that teaching is the main function of the University but ... the University has inescapable duties to the most talented members of each generation, that is, to those capable of making contributions to the development of knowledge. We believe that the University fails in this obligation if the teaching it provides is not imbued with the spirit of enquiry as it is embodied in the tradition of research. Teaching which is not linked with research is on a lower plane, and does not stimulate the best intellects of successive generations of students.
The two activities of the University, teaching and research, should be co-ordinated and combined; and this fusion can, and should, be made a very natural one. Most research workers have a strong desire to teach since, to a considerable extent, teaching is necessary for their research work. Ideas are developed and clarified by imparting them orally to others, and by subsequent discussion in tutorials or seminars. Further, the real research worker feels the urge to hand on the torch of which he is the bearer, thereby perpetuating the tradition of the search for knowledge. On the other hand, teaching on a high level is impossible without research. One reason, in Hill's words, is that "where there is no zeal for research there is no vitality in teaching", but a more fundamental reason is that, without research, teaching can never reach right to the frontiers of knowledge.

Our postulate that teaching and research should be combined does not imply that in individual cases members of the University should not specialize in one of the two activities. We believe, however, that in a University such specialization should never be complete.

If the ideal sketched above is to be realised in New Zealand it is essential that the research function of the University teacher should be fully recognised. The commonly held view that the University is primarily a teaching institution should be abandoned, and the University should be looked upon as an institution in which the spirit of free inquiry is preserved and cultivated. (Allan et al., 1991, p. 72)

\section{Popper's Legacy}

In exploring Popper's legacy - the Canterbury Declaration - I will confine myself to outlining some of the implications of the document for teacher educators, in the critical spirit Popper so forcefully exemplified in his own philosophical work.

As teacher educators, our teaching must be linked to research for a number of very good reasons. First, students are entitled to be informed of the very latest or the very best ideas and findings about past and present educational theories, policies and practices. We have a responsibility to ensure that in both our direct teaching in lectures and tutorials, and in required and recommended reading for discussions and assignments, that students are provided with opportunities to access research literature at the cutting edge of the areas they are studying. Students are not always best placed to know what literature is available 
nor where to find it, so informed direction from "experts" in the field is required. They must not be denied the opportunity to engage with the very best writings available simply because, for whatever reason, academic staff fail to bring it to their attention. To deny students access to research is to leave them in a state of ignorance of that which should be made available to them.

Secondly, on most educational topics of interest to teacher educators and their students, there is widespread national and international disagreement about how to conceptualise any particular problem or issue, how to theorise about it, what evidence is relevant to it, how the evidence is to be collected and assessed, which policies best state the desired ends, and what practices are best suited to achieve such goals. This diversity of thought, or theoretical pluralism, cannot and ought not to be shut down by a refusal of teacher educators to engage with the literature by bringing it to the notice of their students. A good example concerns the teaching of reading and research into how children learn to read. On teaching to read: phonics or whole language? On research into how children learn to read: experimental/scientific or interpretive studies? In New Zealand, these are keen, and keenly felt, topics of debate. On the side of phonics are some of the country's leading experimental/scientific researchers: Chapman, Greaney, Nicholson, Prochnow, Tunmer. On the other side, advocating whole language and interpretive inquiry, are more reading experts: Elley, Limbrick, McNaughton, Smith. They are all eminent in their field of reading and reading research, yet deeply divided. ${ }^{3}$ To illustrate, consider the following two quotes, admittedly from one side of the debate only:

New Zealand teachers assume that learning to read is best when it is informal, natural, spontaneous, continuous and enjoyable. So the experimentalists' findings are inevitably difficult to relate to New Zealand classroom programmes. Some of us read and note their elegantly designed studies with interest, but we do not use their findings to undermine a tried philosophy that works well for most children. (Smith \& Elley, 1996, p. 89)

And:

A classical study involving large numbers of subjects and sophisticated statistical analyses [is] only one form of evidence. The evidence [has] to be weighed against the anecdotal evidence of practising teachers, together with a substantial body of qualitative research that supports the use of context as the primary cue to be used by beginning teachers.... A narrow experimental research programme may not assist with classroom practices. What is published in referenced international journals, while satisfying strict criteria for university-based research, may be of little help in the complex world of the classroom. (Smith, 2000, pp. 141-142)

Such is the divide, that it is legitimate to ask of all the above-named teacher educators: do those advancing either the phonetics/science or the whole language/interpretivist positions give their students a fair and equal opportunity to read, and in their assignments assess, the contentious aspects of the reading debates. Or, does a commitment to, say, reading recovery programmes in the Ministry of Education, teacher education institutions and schools, predetermine teaching content, thereby "closing down the conversation" (Smith \& Heshusius, 1986) by excluding rival thought from serious consideration? In short, do we as teacher educators steer our students into a particular set of views (our own), or do we, in a spirit of intellectual liberty, educate them to make their own rationally critical judgements about such matters? Is there a danger of students being indoctrinated to become well-socialised teachers rather than being educated to become educators themselves?

Thirdly, intellectual liberty demands, from academic staff in particular, but no less from their students, a confrontation with the clash of ideas, of entering into rational dialogue and critical analysis where all ideas, favoured or not, are subjected to the harshest and most rigorous criticism and, if found wanting, refuted. There has been no greater defence of intellectual freedom than that of John Stuart Mill's "On Liberty". He wrote:

First, if any opinion is compelled to silence, that opinion may, for aught we can certainly know, be true. To deny this is to assume our own infallibility

Second, though the silenced opinion be an error, it may, and very commonly does, contain a portion of truth; and since the general or prevailing opinion on any subject is rarely or never the whole truth, it is only by the collisions of adverse opinions that the remainder of the truth has any chance of being supplied.

Thirdly, even if the received opinion be not only true, but the whole truth, unless it is suffered to be, and actually is, vigorously and earnestly contested, it will, by most of those who receive it, be held in a manner of a prejudice, with little comprehension or feeling of its rational grounds. And not only this, but, fourthly, the meaning of the doctrine itself will be in danger of being lost, or enfeebled, and 
deprived of its vital effect on the character and conduct: the dogma becoming a mere formal profession, inefficacious for good, but cumbering the ground, and preventing the growth of any real and heartfelt conviction, from reason or personal experience. (Mill, 1962, pp. 180-181)

Fourthly, if, as teacher educators, our teaching is to be research-based, and if we are to be in an informed position to assist our students to read, assess and critique, even reject, the research they read, then we ourselves must be knowledgeable about not only the content of the research, the substantive arguments and findings about this or that, but also about the adequacy of the research and its methodology. Academic staff who, themselves, do not read research and, more importantly, do not engage in research and so fail to confront methodological issues in research head-on, are in no rational position to help their students critically assess research. How can a teacher educator possibly guide students in their reading of philosophical, historical, experimental, survey or participant observation research if they themselves have no understanding of the scholarship required to undertake such research? The blind leading the blind is no basis for rational inquiry. Informed methodological understanding is needed, and such understanding is best acquired through immersion in the relevant research literature, and through having undertaken and kept up-to-date with particular research strategies, methods and techniques relevant to their general field of study and the particular problems they investigate. In this regard, I would argue that masters degrees are a bare minimum, doctorates are preferable. ${ }^{4}$

Whose research should we ask our students to read? A trite answer is: the very best research! But this is not particularly helpful. A more thoughtful response might be: a selection of good national and international research which introduces students to the key questions, topics, issues, problems and theories of the field which we choose to cover in our teaching. Here, as teacher educators, we make, or should make, sound academic judgements about the research literature our students ought to be introduced to. Often this is the work of others. But I would suggest a stronger requirement still: our students, wherever possible, ought to engage with our own research, that is, with the research of those who teach them. Why so? Two arguments suggest themselves.

First, by doing so we submit our ideas to the scrutiny of others who are in a position to offer us feedback on what they think of the positions we have advanced. When we respond, critical dialogue ensues. Now, this may not be as insightful as the comments of peer reviewers, but the former can offer ongoing intellectual stimulation which the latter lacks. In the tutorial or the assignment, one's ideas are put to the test, and the very best of our students will, if encouraged, put our claims to the strongest critique that they can muster. What more could we ask of our students than this in their quest to become educated and in our duty to help them become so.

Secondly, when our students engage with our own research, they will often readily acknowledge the greater personal worth of their learning, for they can quickly grasp that their teacher is an active researcher making a contribution to the field being taught. If the degrees we teach are to have any worth, nationally and internationally, then our students are surely entitled to have evidence for the claims we make that our teaching is up to such standards of excellence. What better way to do this than to put our own research alongside that of our national and international peers? Students who read our research in refereed overseas journals can surely have a high measure of confidence that they are being taught by the best in the field. The same is true when we incorporate our own research into texts for our students. ${ }^{5}$ We need to utilise our research to make good our claims that the quality of our teaching stands up to the closest scrutiny.

Students will respond positively, for it is research by New Zealand writers on matters of New Zealand education that often captures their interest and imagination, and so it has a measure of personal meaning to them that overseas literature may not always capture because of different contextual features. This will have a major effect on our teaching, because we can become passionately involved in debating and defending our own views in a way that is more powerful than when it is someone else's ideas we are addressing.

\section{Institutional Mergers and the PBRF}

If teacher educators are going to include their own research in their teaching, this implies that they are duty bound to actively engage in research. This has brought both gains and pains. Two specific instances will be considered:

- Institutional mergers

- Performance Based Research Fund (PBRF). 
With regard to institutional mergers, four colleges of education have merged with universities, and the remaining two are likely to do so in the near future. One virtue of this has been that former college staff members have been provided with greater research opportunities, such as conference leave, undertaking higher degrees, publishing journal articles and books, supervising post-graduate students and the like. If we, as teacher educators, are to take the teaching/research relationship seriously, as we must, then a number of inescapable entailments must be confronted head-on.

First, students have a right to be taught by teachers who are research active. First and foremost it is the universities which provide this, which seems a good reason for teacher education to be university-based.

Secondly, if teacher education students have a right to be taught by the very best researcher-teachers, then it follows that in the various academic subjects studied, be they English, mathematics, science or whatever, these are best studied in university departments of English, mathematics, science and the like, where the most productive researcher-teachers in these fields are to be found. (It should be noted that this refers to the content of these subjects, and not to pedagogical aspects of how they are actually taught.)

Thirdly, bench-marking is necessary. Teacher education students must not be quarantined from the rest of the student body. They should take papers that other students take. How better to establish parity of standards (and the elimination of a stigma of inferiority) than to require the same standards of achievement for all. Pre-service teacher education students should be the equal of their BA/BSc peers. These three considerations lead to the obvious conclusion that with institutional mergers, teacher educators and their students must be physically located on the main campus and not relegated to the colonies of remote sites where the isolation from academic colleagues leads to the loss of contact and a reduction in intellectual growth.

Fourthly, it really does need to be asked whether the current three year pre-service degrees are up to the task of achieving the level of intellectual independence one would expect of all students in the academy? For example, the BA degree might be regarded as a good standard for research-based teaching in the humanities and social sciences: a full three years is the minimum time required. In this respect the pre-service teacher education degree such as the BEd (Tchg) falls well short of being equivalent in preparing students to the same intellectual level, once the time taken for teaching practice is deducted. It could well be asked whether the two and a half years of study undertaken by teacher education students matches the three years of other degrees. Perhaps the parity of degrees can only be restored if pre-service teacher education students engage in a minimum of four years of study, either as a four year degree or as conjoint degrees taken over four years.

On the Performance Based Research Fund (PBRF) a word of warning is appropriate at the outset. The Tertiary Education Commission report included a comparison of New Zealand and British universities. ${ }^{6}$ In the United Kingdom, the Research Assessment Exercise 2001, the latest in a series (with the next scheduled for 2008), is a salutary lesson for New Zealand. Of the 83 education units surveyed (some single departments, others whole institutions such as the University of London Institute of Education), 14 were graded 5 or $5^{*}$ and so were awarded research funding. The remaining institutions graded $0-4$ will not receive any such funding.

In New Zealand, the PBRF results for Education make interesting reading. The relevant tables contain a considerable amount of information which is set out in a simplified form in Table 1 (Tertiary Education Commission, 2004a). It is no surprise that the universities should occupy the top positions, followed by the colleges of education. This was to be expected. It is no surprise that the University of Auckland leads the list. This, too, was expected.

However, the rankings of the six universities with major programmes in Education are problematic. The first four (excluding Lincoln) are all single units separate from their local colleges of education, whereas Waikato and Massey are multi-department merged units. In his press release (2004, April 23) on the PBRF results, the vice-chancellor of the University of Waikato, Professor Bryan Gould, had this to say:

It's all the more satisfying that our overall placing of a close fifth in research quality was achieved despite the fact that we have been merged with a teachers college for some time, and staff at that college did not traditionally do a lot of research. Auckland and Otago are in the process of merging with teachers colleges so it will be interesting to see what effect this has on their performance under PBRF in the future. 
Table 1 PBRF Rankings 2004 - Education

\begin{tabular}{|c|c|c|c|c|c|c|c|}
\hline Rank & Institution & Quality & A & B & $\mathrm{C}$ & $\mathbf{R}$ & Elig \\
\hline 1 & Auckland University & 3.6 & 11 & 17 & 27 & 18 & 73 \\
\hline 2 & Victoria University & 2.6 & 1 & 7 & 7 & 10 & 25 \\
\hline 3 & Otago University & 2.1 & 2 & 4 & 11 & 14 & 31 \\
\hline 4 & Lincoln University & 2.0 & 0 & 0 & 1 & 0 & 1 \\
\hline 5 & Canterbury University & 1.8 & 1 & 2 & 13 & 10 & 26 \\
\hline 6 & Waikato University & 1.8 & 6 & 20 & 33 & 78 & 137 \\
\hline 7 & Massey University & 1.4 & 5 & 14 & 37 & 94 & 150 \\
\hline 8 & Unitec & 0.9 & 0 & 3 & 4 & 23 & 30 \\
\hline 9 & $\begin{array}{l}\text { Auckland University of } \\
\text { Technology }\end{array}$ & 0.5 & 0 & 2 & 8 & 45 & 55 \\
\hline 10 & $\begin{array}{l}\text { Auckland College of } \\
\text { Education }\end{array}$ & 0.3 & 0 & 1 & 22 & 134 & 157 \\
\hline 11 & $\begin{array}{l}\text { Dunedin College of } \\
\text { Education }\end{array}$ & 0.2 & 0 & 0 & 7 & 59 & 66 \\
\hline 12 & $\begin{array}{l}\text { Christchurch College of } \\
\text { Education }\end{array}$ & 0.2 & 0 & 1 & 13 & 137 & 151 \\
\hline 13 & Te Wananga o Aotearoa & 0.1 & 0 & 0 & 1 & 18 & 19 \\
\hline 14 & $\begin{array}{l}\text { Wellington College of } \\
\text { Education }\end{array}$ & 0.0 & 0 & 0 & 2 & 117 & 119 \\
\hline 15 & $\begin{array}{l}\text { Bethlehem Institute of } \\
\text { Education }\end{array}$ & 0.0 & 0 & 0 & 0 & 22 & 22 \\
\hline 16 & Bible College of NZ & 0.0 & 0 & 0 & 0 & 1 & 1 \\
\hline 17 & $\begin{array}{l}\text { Wellington Institute of } \\
\text { Technology }\end{array}$ & 0.0 & 0 & 0 & 0 & 13 & 13 \\
\hline 18 & $\begin{array}{l}\text { Whitecliff College of Arts } \\
\text { And Design }\end{array}$ & 0.0 & 0 & 0 & 0 & 1 & 1 \\
\hline \multicolumn{2}{|c|}{ Total Education } & 1.0 & 26 & 71 & 186 & 794 & 1077 \\
\hline
\end{tabular}

(TEC, 2004a, p. 132, adapted)

Note: The column headed Elig contains the total number of eligible staff.

The Quality score, which determines institutional ranking, is calculated by adding the weighted scores $(A=5, B=3, C=1, R=0)$, multiplying by 2 , and then dividing by the total number of PBRF eligible staff (TEC, 2004a, pp. 37-38)

Victoria University of Wellington and Wellington College of Education have recently merged. The New Zealand Education Review reported thus:
At the council meeting earlier this month, Vice-Chancellor Stuart McCutcheon said the only significant risk to the university was the impact on its profile in the Performance Based Research Fund (PBRF). Colleges of Education scored low in the PBRF quality ranking and Wellington was the lowest-scored public tertiary institution with an average quality score of 0.03 .

But McCutcheon said mitigating that risk was the likelihood that the four remaining colleges would merge with universities in the near future, "thereby levelling the playing field somewhat." (Nixon, 2004, p. 4)

One way of "levelling the playing field somewhat" would be to combine the PBRF results of each university with the PBRF results of the local College of Education. Now, a very different picture emerges (Table 2).

Table 2 PBRF Rankings 2004 - Revised

\begin{tabular}{llcrrrrr}
\hline Rank & Institution & Quality & A & B & C & R & Elig \\
\hline 1 & Waikato & 1.8 & 6 & 20 & 33 & 78 & 137 \\
2 & Massey & 1.4 & 5 & 14 & 37 & 94 & 150 \\
3 & Auckland/ACE & 1.4 & 11 & 18 & 49 & 152 & 230 \\
4 & Otago/DCE & 0.8 & 2 & 4 & 18 & 73 & 97 \\
5 & Canterbury/CCE & 0.4 & 1 & 3 & 26 & 147 & 177 \\
6 & Victoria/WCE & 0.2 & 1 & 7 & 9 & 127 & 144 \\
\hline
\end{tabular}

When like are compared with like, Waikato (1.8) and Massey (1.4) do much better, followed by Auckland ${ }^{7}$ (but with its Quality Score reduced from 3.6 to 1.4 ), while Otago (2.1 to 0.8 ), Canterbury (1.8 to 0.4 ) and Victoria (2.6 to 0.2$)$ fare poorly.

A good feature of this exercise is that the research activity of New Zealand tertiary institutions is transparent, recognised and rewarded, rather than being overshadowed by being embedded in the Equivalent Full-time Student (EFTS) funding for teaching. It is also peer reviewed at departmental, institutional and national levels. The not so good featuresinclude: classifying active researchers (e.g., those doing doctoral studies) as "research inactive" (Coded R) because of inappropriate criteria (much subsequent criticism has been raised against this classification, and it is possible that a category of "new/inexperienced" 
researcher will be included in the future, thus allowing this research activity to be recognised and funded); a danger that the value placed on research will be at the expense of the value placed on teaching because of funding and status; a greater emphasis on individual, departmental and institutional competition rather than collaboration in the pursuit of the highest research rankings; and considerable pressure on supervisors and (usually) part-time students regarding criteria for entry into, and completion of, theses in order to meet PBRF requirements.

All of this should lead to increased institutional accountability. An example from the UK may illustrate this. In the Research Assessment Exercise 2001, the University of Exeter slumped in its overall ranking, under the vice-chancellorship of a former permanent under-secretary of education. The new vice-chancellor, an academic with a political science background, has set out to recover lost ground. During the academic year, each and every head of department meets with the vice-chancellor to report on the research activity of all departmental staff. Such is the effect of research rankings. Will we see similar accountability practices established here?

Finally, research will only benefit policy and practice if it is put into the hands, or more accurately into the heads, of those who in one way or another engage in policy or practice. They cannot be expected just to go into the library and find the research. That is expecting far too much of them, for few will do so unaided. It is in our teaching to pre-service and in-service teachers, as well as to administrators, policy makers and the like that we bring research, our own and that of others, to bear on what our students think and do. Research which sits on the shelf may make a contribution to the advancement of the field, but if it is left unread by ourselves and others then there is little chance of it making any impact at all on either their thinking or ours. Our students need to be critical, rational practitioners.

\section{Concluding Remarks}

Where then, does all of this leave us? It is clear that the PBRF places a premium on research, for both institutional reputation in the rankings and the receipt of research funding on the basis of results. Whether we like it or not, and many in teacher education do not, the PBRF is here to stay, albeit in a revised form. In this respect, the institutional mergers of universities and colleges of education will, for the first time, put all six merged institutions on a level playing field (or would have done if the University of Auckland had not successfully persuaded the TEC that for
PBRF 2007 results from the former university school of education should be kept separate from those from the Auckland College of Education, and not combined). The mergers, if they are to be effective, will require the bringing together of more and less experienced researchers, with the expectation that the former will need to devote some of their research time assisting the latter to become more research active. The development of a coherent research culture takes considerable time and requires both commitment and effort as well as substantial institutional support (rather than asset stripping). What matters most is that a vibrant, vigorous and systematic research culture is promoted and allowed to flourish, the achievement of which falls on all staff, but in particular on experienced researchers and senior administrators to provide both leadership and resources (time, money, etc) to let this happen. But there is a very real danger that this long-term goal will be undermined by the short-term, financial dictates of PBRF which not only introduce unnecessary individualism and institutional competition at a time when collaboration is called for, but also may give a public signal to others (politicians, policy-makers, TEC and the community) that, because of its low ranking against other subjects, educational research has a low level of productivity and so is not worthy of the level of funding it deserves. If this conclusion is drawn then it would be a travesty of justice, for there can be few more worthy beneficiaries of research than teachers and the children they teach.

To conclude with a thought and an imperative. The thought is this: Kant wrote something to the effect that "Theory without practice is empty, practice without theory is blind." Likewise, it could be said, "Research without teaching is empty, teaching without research is blind." And so to the imperative: every teacher educator has an ethical duty to give to his or her students the very best of themselves as educators whose teaching is research-based and whose research is teaching-orientated. Of this we can ask no more and expect no less.

Notes

1. Section 162 (4) (b)( i) - (iv) states:

(i) A college of education is characterised by teaching and research required for the pre-school, compulsory and post-compulsory sectors of education, and for associated social and educational service roles;

(ii) A polytechnic is characterised by a wide diversity of continuing education, including vocational training, that contributes to the maintenance, advancement, and dissemination of knowledge and 
expertise and promotes community learning, and by research, particularly applied and technological research, that aids development.

(iii) A university is characterised by a wide diversity of teaching and research, especially at a higher level, that maintains, advances, disseminates, and assists the application of, knowledge, develops intellectual independence, and promotes community learning.

(iv) A wananga is characterised by teaching and research that maintains, advances, and disseminates knowledge and develops intellectual independence, and assists the application of knowledge regarding ahuatanga Maori (Maori tradition) according to tikanga Maori (Maori custom).

2. The signatories to the document "University Research in New Zealand" were: R. S. Allan (Professor of Geology, Canterbury); J. C. Eccles (Professor of Physiology, Otago, later Professor of Physiology at the Australia National University and Nobel Prize Winner in Physiology and co-author with Karl Popper of The Self and the Brain); H. G. Forder (Professor of Mathematics, Auckland); J. Packer (Professor of Chemistry, Canterbury); H. N. Parton (Senior Lecturer in Chemistry, Canterbury, and later Professor of Chemistry, Otago); and K. R. Popper (Senior Lecturer in Philosophy, Canterbury, and later Professor of Logic and Scientific Method at the London School of Economics).

3. At the joint Australian and New Zealand Associations for Research in Education Conference, held in Auckland in 2003, a three-session symposium brought together all of those listed here, plus Nash, Openshaw and the author, to explore the Progress in International Reading Literacy Study (PIRLS) results. All of the symposium papers have been published in Delta, 56(2), 2004 and clearly reveal the deep divisions in the field on teaching reading and reading research.

4. Many, probably most, doctorates (EdD, PhD) are undertaken by staff and students on a part-time basis. Parton (1991, p. 75) remarked that the PhD was first awarded by the University of New Zealand from 1922-26, until difficulties arose over the requirement for full-time work, which led to its abolition; only after World War Two was the PhD reintroduced, following the 1946 initiative of a new Chancellor, Sir David Smith, who devoted his first address to an inquiry into the place of research in the university. One outcome was that the then Director of Education, Dr C. E. Beeby, who was a member of the Council of the University of New Zealand, included in his department vote for 1946-7 the sum of $£ 10,000$ for University research.
5. My colleagues and I have made available to our students our thinking on many matters educational. Some examples are: Adams et al. (2002), Education and Society in Aotearoa New Zealand; O'Neill et al. (2004a), Reshaping Culture, Knowledge and Learning: Policy and Content in the New Zealand Curriculum Framework; O'Neill et al. (2004b), Examining the New Zealand Curriculum Framework: Contexts, Issues and Assessment; and Adams et al. (2005), Teachers' Work in Aotearoa/New Zealand.

6. Following legal action in the High Court by two universities, the TEC removed this section of their report prior to public release.

7. TEC, unfortunately, in my view, accepted the argument put forward by the University of Auckland that, despite the merger with Auckland College of Education in 2004, the two institutions should be kept separate for PBRF 2007. This appears to have been done for political rather than educational reasons. The same courtesy was not extended to the earlier merged institutions, and at the time of writing it is not clear that it will be extended to the other newly merged institutions, or to the two pairs about to be merged.

\section{References}

Adams, P., Clark, J., Codd, J., O’Neill, A-M., Openshaw, R., \& Waitere-Ang, H. (2000). Education and society in Aotearoa New Zealand. Palmerston North: Dunmore Press.

Adams, P., Vossler, K., \& Scrivens, C. (Eds.). (2005). Teachers' work in Aotearoa New Zealand. Southbank, Victoria: Thompson.

Allan, R., Eccles, J., Forder, H., Packer, J., Parton, M., \& Popper, K. (1991). Research and the university. New Zealand Science Review, 48(3-4), pp. 72-73.

Gould, B. (2004, April 23). Waikato University does very well in PBRF. Press release.

Mill, J. S. (1962). Utilitarianism. London: Fontana.

Nixon, M. (2004). Wellington merger decision nears. New Zealand Education Review, 9(18), 4.

O’Neill, A-M., Clark, J., \& Openshaw, R. (Eds.). (2004). Reshaping culture, knowledge and learning: Policy and content in the New Zealand Curriculum Framework. Palmerston North: Dunmore Press.

O'Neill, A-M., Clark, J., \& Openshaw, R. (Eds.). (2005). Critically examining the New Zealand Curriculum Framework: Contexts, issues and assessment. Southbank, Victoria: Thompson. 
Parton, H. (1991). University research in New Zealand. New Zealand Science Review, 48(3-4), 74-75.

Plato. (1969). The apology. London: Penguin.

Popper, K., \& Eccles, J. (1984). The self and the brain. London: Routledge \& Kegan Paul.

Royal Commission on University Education in New Zealand. (1925). Report (Reichel-Tate). Wellington: Government Printer.

Smith, J. (2000). The literacy taskforce in context. In J. Soler \& J. Smith (Eds.), Literacy in New Zealand: Practices, politics and policies since 1900 (pp. 134-143). Auckland: Pearson Education.

Smith, J., \& Elley, W. (1996). Making sense out of nonsense. New Zealand Journal of Educational Studies, 31(1), 85-89.

Smith, J., \& Heshusius, L. (1986). Closing down the conversation: The end of the quantitative-qualitative debate among educational inquiries. Educational Researcher, 15(1), 4-12.

Tertiary Education Advisory Commission (TEAC). (2001). Shaping the Funding Framework. Wellington: TEAC.

Tertiary Education Commission (TEC). (2004a). Performance Based Research Fund, evaluating research excellence: The 2003 assessment. Wellington: TEC.

Tertiary Education Commission. (2004b). The distinctive contribution of tertiary education organizations. Wellington: TEC

\section{The author}

John Clark is a Senior Lecturer in the Department of Social and Policy Studies in Education, Massey University, Palmerston North. His teaching and research interests are in philosophy of education, especially ethics, curriculum, research and policy.

Email: J.A.Clark@massey.ac.nz 